\title{
Impact Of Abattoir Waste On The Physico-Chemical Quality Of Anwai River, Asaba Delta State, Nigeria
}

\author{
Ezemonye, Mary N. \\ Osiatuma, Stephanie I. \\ Department of Geography and Regional Planning, \\ University of Benin, Benin City, Nigeria \\ Emeribe, Chukwudi N. \\ National Centre for Energy and Environment, \\ Energy Commission of Nigeria, University of Benin
}

doi: 10.19044/esj.2016.v12n20p277 URL:http://dx.doi.org/10.19044/esj.2016.v12n20p277

\begin{abstract}
Abattoir management is left in the hands of the populace and to this end, the wastes generated thereof are handled without consideration of the impacts on the environment. The study established quality deterioration for rainy/dry season physicochemical parameters at downstream (points after the abattoir) as theyexceeded values of the control point (sample site before the abattoir). The analysis of variance test at 0.05 confidence level supports the fact that quality of Anwai River at effluent discharge point differ significantly from quality at control point during rainy season. The rainy season values of the physicochemical parameters for slaughter days far exceeded the non slaughter days. The ANOVA test to determine if dry season quality of the Anwai River at effluent discharge point differ significantly from quality at control point showed no statistical variation at 0.05 level of confidence of confidence suggesting reduced diffused pollution and transportation of pollutant during the dry season. The study also established that the season of the year does have effect on quality deterioration of Anwai River. Diffuse pollution was established to on Anwai River as a result of poor abattoir waste management. It is recommended that the State government intervenes to stem the indiscriminate disposal of abattoir waste into the river to help preserve the health of the river and Anwai community.
\end{abstract}

Keywords: Abattoir, Effluent, River, Water quality, Physico-chemical, Pollution 


\section{Introduction}

The quality of drinking water is a perquisite in determining the health of any society thus good quality water is indispensible for preventing water borne diseases and improving quality of life. Attaining high quality of drinking water therefore has been a key pillar for diseaseprevention for over one and a half centuries and continues to be the foundation for the prevention and control of water borne diseases (WHO, 2010). The reason for water being so predominant among the Millennium development Goals (MDGs) is the view that poor quality of drinking water and improper disposal of wastewater have serious impact on human health. Similarly, the interdependence between water availability and development in Africa is exemplified by the link between water and poverty. For example, Gbadegesin and Olorunfemi (2007) observed that due to inadequate access to safe water and sanitation, there is a high incidence of communicable diseases that reduce vitality and economic productivity on the continent.

Unabated pollution of fresh water unfortunately continues to be a sources of concern in developing countries. This problem is compounded by population pressure, lack of improper implementation of pollution laws and possible impacts of changing climatic pattern as more people pollute the water while at the same time demanding more of it for survival. The slaughter of animals for human consumption produces various and large quantities of wastes. Thus the activities of abattoirs represent an important source of contamination to surface and ground water sources in developing countries where abattoir management is poorly coordinated and wastes generated are simply channeled into river bodies. In Nigeria, abottiors are usually located near river bodies in an attempt to have assured access to mater for processing of slaughtered animals.

The animal blood is also released in its untreated form into the flowing streams while the consumable parts of the slaughtered animals are washed directly into the flowing water (Akan et al, 2010). Abattoir effluent contains high levels of organic matter due to the presence of manure, blood, fats, grease, hair, grit, and undigested feeds (Kosamu et al 2011) all of which deteriorate the quality of surface water.The large quantity of salt in animal manure, including sodium, calcium, magnesium, potassium, chloride, sulphate, bicarbonate, carbonate, and nitrate have the potential to increase the salinity of waterways, leading to changes in aquatic ecosystems and making water brackish, and therefore unfit for drinking (Sandra et al, 1996).

Anwai River is a major river that drains the Anwai community. It receives untreated abattoir effluent (Plate 1), yet the community depends greatly on this water source for domestic purposes. This study therefore aims to determine the impact of the abattoir activities on water quality 
characteristics of Anwai River as well as make recommendations for Sustainable management of the community water source.

\section{Methodology}

\section{Study area}

River Anwai is Located between latitude $6^{0} 15^{\prime N}$ and $6^{0} 20^{\prime N}$ and Longitude $6^{0} 23^{\prime} \mathrm{E}$ and $6^{0} 06^{\prime \mathrm{E}}$. The study area is Anwai, which is a small community in Asaba. The community is very close to river Niger. Anwai River is a fresh inland water body that flows from Otulu in Aniocha South Local Government Area through the hills and rocks of Ugbolu village and empties into River Niger in Oshimili South Local Government Area of Delta State(Fig 1).Anwai is one of the smallest communities in Asaba, in Oshimili South Local Government Area. Anwai belongs to the Ibo speaking people of Delta State. There are few industries in Anwai, however smallscale industries abound in the area. With the creation of Delta State with Asaba as State capital, Anwai has assumed the role of a satellite community housing many private secondary schools and Delta State University satellite campus. This has contributed to the population growth of the community. The Anwai River serves as a major source of water for domestic purpose all year round; while having a peak demand in the dry season. 


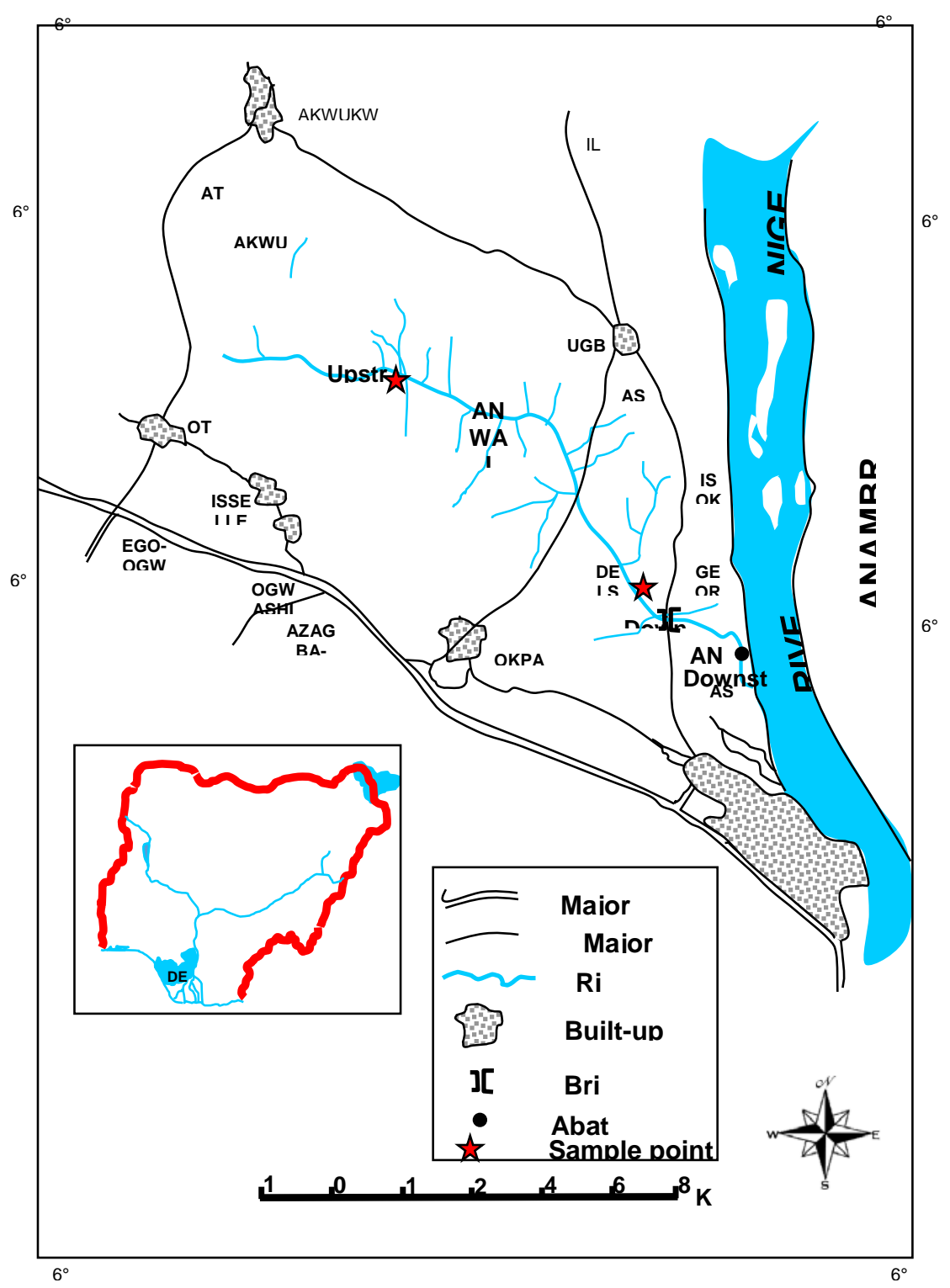

FIG. 1.2: ANWAI SHOWING SAMPLE SITES

Source: Ministry of Lands and Survey, Asaba, 2013

FIGURE 1: Anwai River System showing the sample Sites

Source: Ministry of Lands and Survey, Asaba, 2013

\section{Data collection}

Water sampling was carried out during the raining and dry seasons for upstream and downstream segment of the river. The data were collected from the various sections located along Anwai River where abattoirs 
effluents are channeled. Collection of water samples was done in the morning hours between 7.am to 8.am, which coincides with the period of animal slaughtering and utilization of the river by butchers. Water samples were collected from two points on the river; upstream and downstream.The downstream sampling point was at the entrance of the abattoir effluent into the river which is about 5meter (downstream). The upstream site which is 50 meters away from the slaughter house was selected based on the desire to have a control site before the slaughter site on the river bank. Water samples were collected during the dry (March) and rainy (July) seasons along the river that drains the abattoir, this is to make it possible to determine the seasonal variation of water quality along the river. In addition, water samples were collected on the days animals were slaughtered and the days animals were not slaughtered for raining and dry seasons.

At each sampling locations, water sample were taken in clean plastic containers, and with BOD and DO bottles. All containers was previously washed and finally rinsed with deionised water prior to useage (Iware et al, 2012). Before taking the sample water, the bottles were rinsed three times with sample water at the point of collection. One millimeter of Winkler A and B was inserted into the DO bottles immediately the water samples are collected, this is to help maintain the sharpness of bacteria present in the water sample before analyzing the sample at the laboratory. The bottles were labeled according to location name. The collected water sample was immediately put in an ice bag cooler to maintain the required temperature and transported to the Benin Owena Basin Research laboratory for analysis.

\section{Data Analysis}

Samples were measured forTemperature, $\mathrm{pH}$, Electrical conductivity, Total dissolve solid (TDS), Total hardness, Nitrate, Phosphate, Sulphate, Dissolve oxygen, Sodium, Iron, Ammonia, Calcium, magnesium and BOD. All analyses were carried out in accordance with standard procedure described in APHA (2005). Results of laboratory analysis were subjected to data evaluation using standard statistical methods (Chapman, 1992) and results from rainy and dry season were compared with WHO water quality guidelines of (2004). Specifically, laboratory result were analysized using graphs, mean, tables and one-way ANOVA.

\section{Results and Discussion}

In Fig. 1, it can be observed that activity of the abattoir impacts greatly on the water quality of Anwai River as values observed at the downstream of sampling point far exceeded values obtained at control which is 50 meters from the slaughter house.From the Laboratory analysis it was deduced that the rainy season figures were as follows, temperature $\left(28.1^{0} \mathrm{C}\right)$ 
, pH, (5.7), turbidity (29.2 NTU), conductivity, (44.6 mg/l), TDS(22.6 mg/l), Hardness $(15.25 \mathrm{mg} / \mathrm{l})$, sulphate $(21.1 \mathrm{mg} / \mathrm{l})$, nitrate $(0.24 \mathrm{mg} / \mathrm{l})$, phosphate $(1.84 \mathrm{mg} / \mathrm{l})$ and ammonia (5.1mg/l), DO (1.77 mg/l), BOD(35.5mg/l), Ca (5.5 mg/l), Mg (0.34mg/l), Fe (2.05 mg/l) and $\mathrm{Na}(4.18 \mathrm{mg} / \mathrm{l})$. These values obtained for rainy season are indicative of the fact that with the exception of temperature, other parameters exceeded the physicochemical quality of water at the control point (Fig. 1). This supports the fact that water quality deterioration resulting from abattoir effluent discharge is apparent.

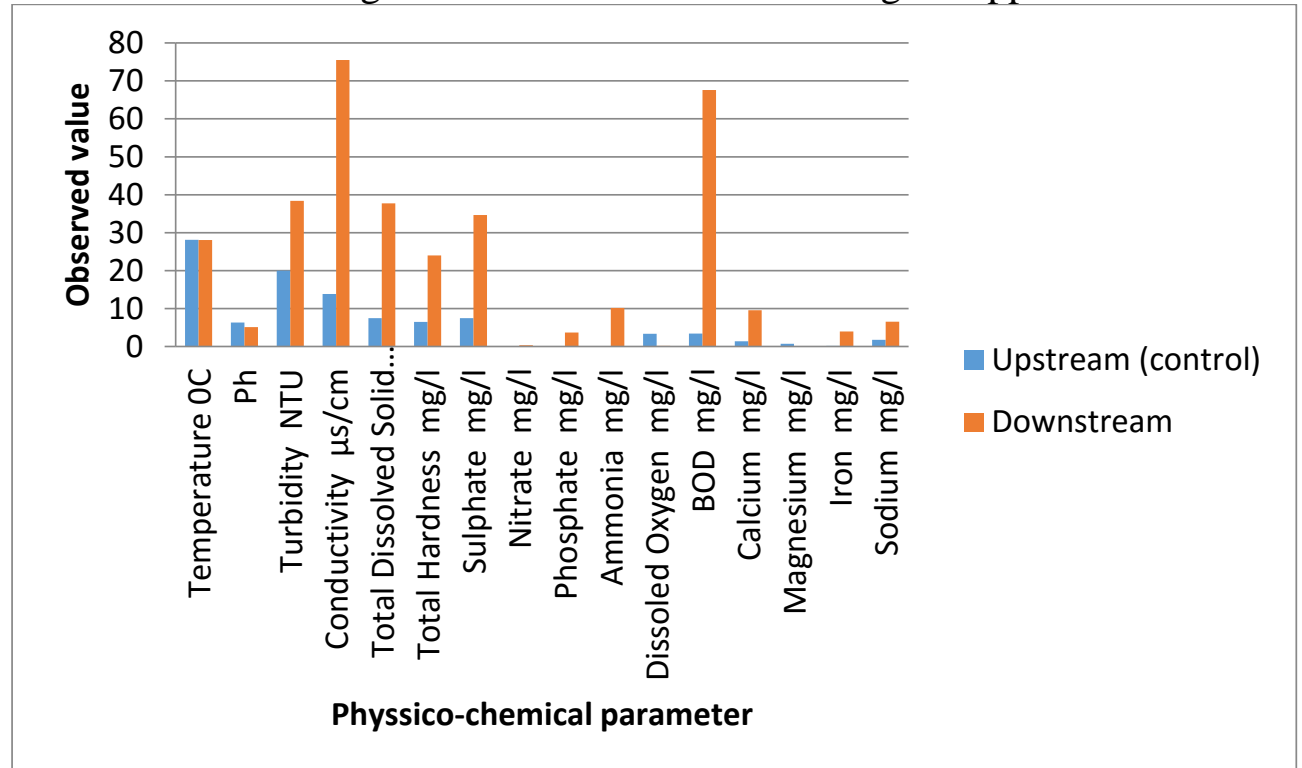

Fig.1 Compared Physico-chemical quality of Anwai river water at effluent discharge point with control (rainy season scenario)

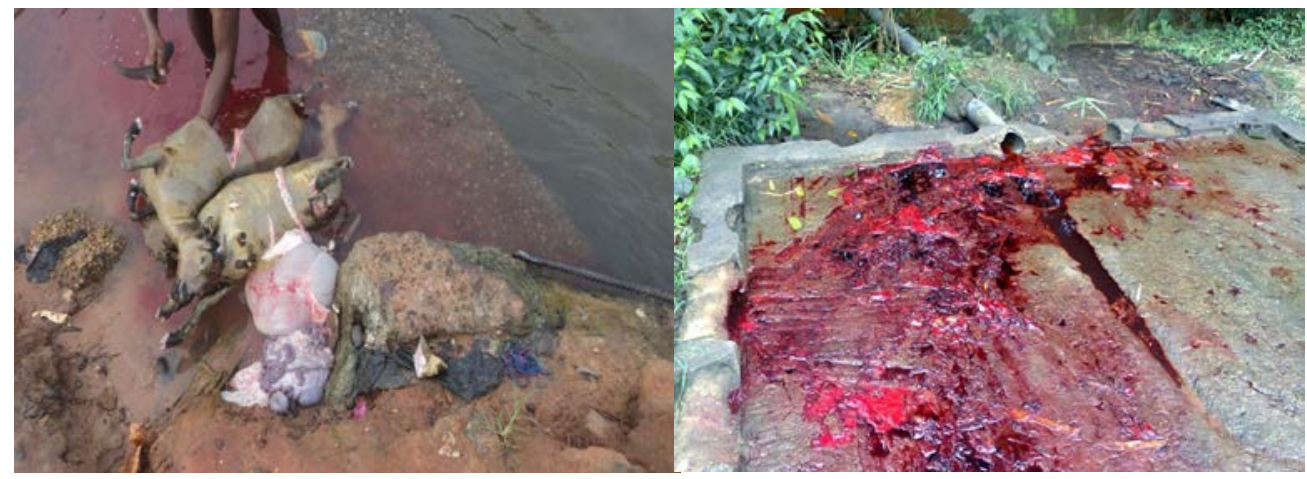

Plate 1: Abattior effluent discharge into Anwai River Source: Author's field work (2014) 
The analysis of variance to test whether the quality of Anwai river water at effluent discharge point differ significantly from quality at control point during the rainy season showed that there significant difference at 0.05 statistical threshold, which buttresses our observation that receiving section of the Anwai river has been greatly polluted (Table 1).

Table 1: Analysis of variance for difference in Physico-chemical quality of Anwai river water between downstream and upstream (control point) rainy season scenario

\begin{tabular}{|c|c|c|c|c|c|c|}
\hline Source of Variation & SS & df & MS & F & P-value & F crit \\
\hline Between Groups & 1871.519 & 1 & 1871.519 & 5.889248 & 0.021452 & 4.170877 \\
\hline Within Groups & 9533.572 & 30 & 317.7857 & & & \\
\hline Total & 11405.09 & 31 & & & & \\
\hline
\end{tabular}

Author's Field work, 2014

Analysis to ascertain the physicochemical quality of Anwai River during the slaughter days and non slaughter days in the rainy season revealed that values of physicochemical parameters for the rainy slaughter days far exceeded observation in the non slaughter days (Fig.2). This can be explained by the possible effects of dilution from rainfall as well as the ability of flowing water to purify itself. Table 2 presents that statistical relationship between quality of water at slaughter and no slaughter days. Our hypothesis that quality of water during the non slaughter day does not differ with water quality on a slaughter day was rejected at 0.05 level of significance, which suggests that deterioration is more during the peak of abattoir activity. This observation may also indirectly, suggest that festivity periods when more animals are slaughtered are expected to have greater impact on pollutant generation.

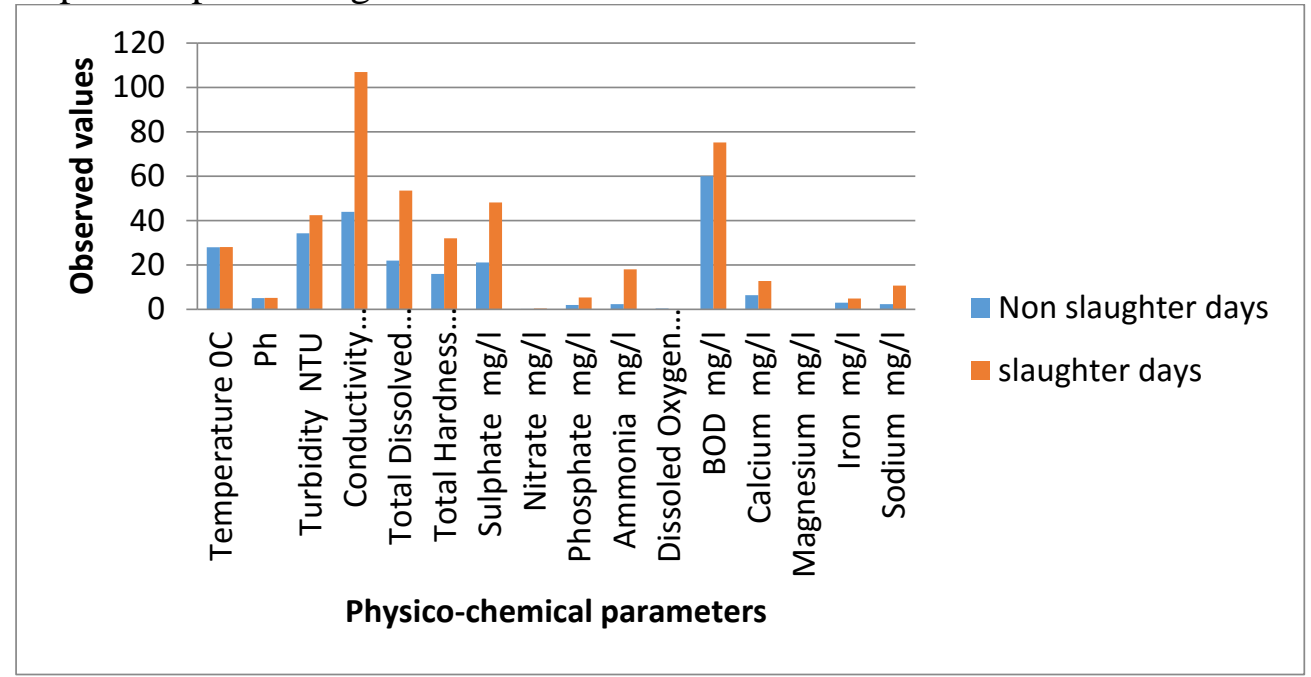

Fig.2 Physico-chemical quality of Anwai river water at effluent discharge point during slaughter and non slaughter days (rainy season scenario) 
Table 2: Analysis of variance for difference in Physico-chemical quality of Anwai river water between slaughter and non slaughter days (Rainy season scenario)

\begin{tabular}{|c|c|c|c|c|c|c|}
\hline Source of Variation & SS & df & MS & F & P-value & F crit \\
\hline Between Groups & 1290.313 & 1 & 1290.313 & 1.990539 & 0.169299 & 4.195972 \\
\hline Within Groups & 18150.24 & 28 & 648.2229 & & & \\
\hline Total & 19440.55 & 29 & & & & \\
\hline
\end{tabular}

Author's Field work, 2014

From the Laboratory analysis it was deduced that the dry season figures were as follows, temperature $\left(28.4^{0} \mathrm{C}\right), \mathrm{pH}(6.6)$, turbidity (7.7 NTU), conductivity $(17.05 \mathrm{mg} / \mathrm{l})$, TDS $(9.0 \mathrm{mg} / \mathrm{l})$, Hardness $(6.0 \mathrm{mg} / \mathrm{l})$, sulphate $(11.5 \mathrm{mg} / \mathrm{l})$, nitrate $(0.15 \mathrm{mg} / \mathrm{l})$,phosphate $0.94 \mathrm{mg} / \mathrm{l})$,ammonia $(1.42 \mathrm{mg} / \mathrm{l})$, DO ( $4.8 \mathrm{mg} / \mathrm{l}), \quad B O D(2.2 \mathrm{mg} / \mathrm{l}), \mathrm{Ca}(1.6 \mathrm{mg} / \mathrm{l}), \mathrm{Mg}(0.5 \mathrm{mg} / \mathrm{l}), \mathrm{Fe}(0.46 \mathrm{mg} / \mathrm{l})$ and $\mathrm{Na}(1.94 \mathrm{mg} / \mathrm{l})$ respectively. These value exceeded physico-chemical quality of water at control point indicating possible pollution from abattoir effluent (Fig. 3).

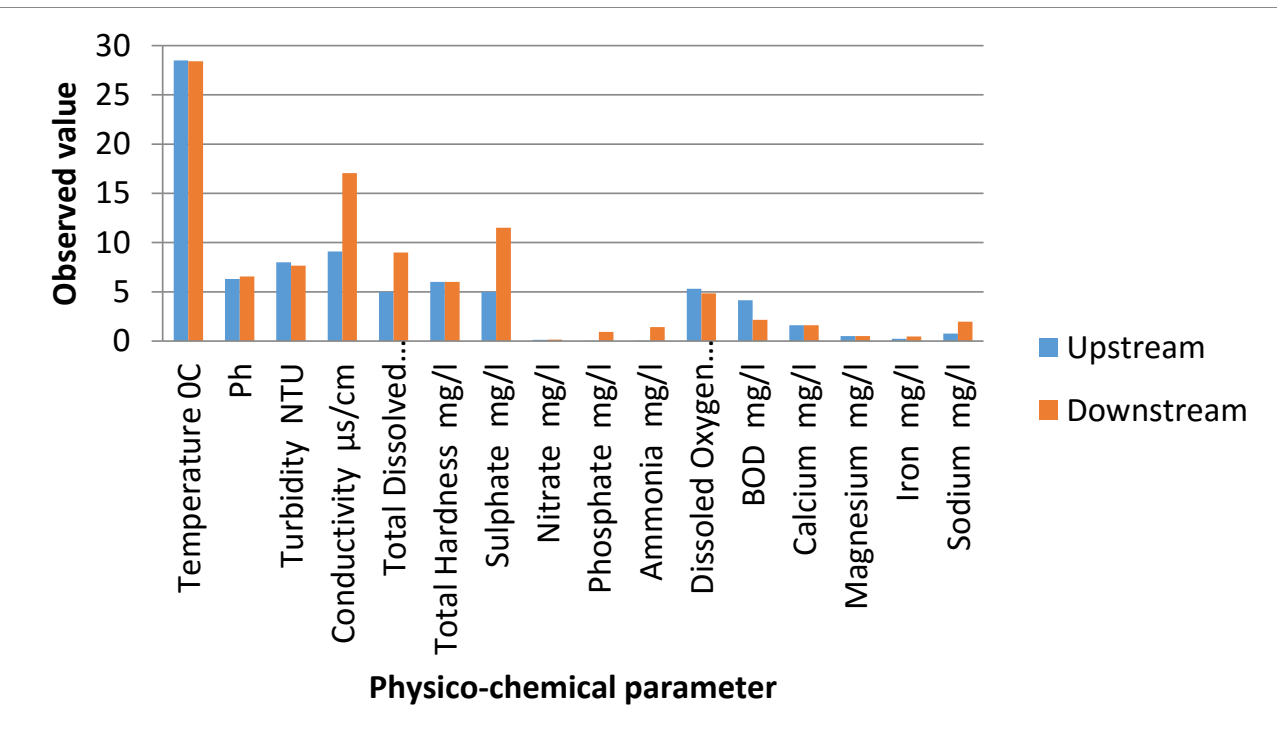

Fig.3 Compared Physico-chemical quality of Anwai river water at effluent discharge point with control (dry season scenario)

Table 3: Analysis of variance for difference in Physico-chemical quality of Anwai river water between downstream and upstream (control point) dry season scenario

\begin{tabular}{|c|c|c|c|c|c|c|}
\hline Source of Variation & SS & df & MS & F & P-value & F crit \\
\hline Between Groups & 11.96828 & 1 & 11.96828 & 0.226322 & 0.63771 & 4.170877 \\
\hline Within Groups & 1586.448 & 30 & 52.8816 & & & \\
\hline Total & 1598.416 & 31 & & & & \\
\hline \multicolumn{7}{c|}{ Author's fieldwork, 2014 }
\end{tabular}


The analysis of variance to determine if the quality of Anwai river water at effluent discharge point differs significantly from quality at control point for the dry season scenario (Table 3) showedthe absence of statistical variation at 0.05 statistical threshold, which suggests reduced diffuse pollution and transportation of pollutant during the dry season.

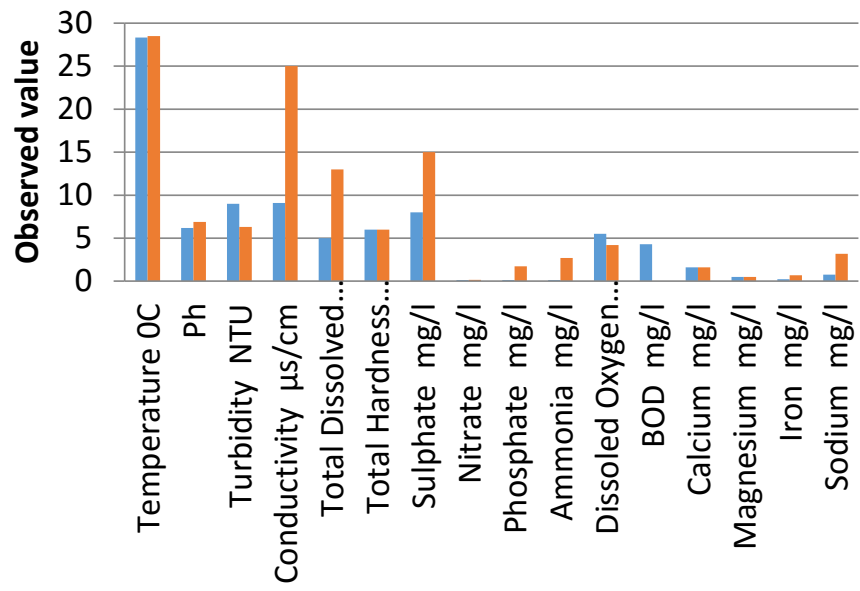

Non slaughter days

Physico-chemical parameter

Fig.4: Physico-chemical quality of Anwai river water at effluent discharge point during slaughter and non slaughter days (Dry season scenario)

The physico-chemical quality of Anwai River water during the slaughter and non slaughter days for the dry season as shown in Fig. 4 indicate that the values of physico-chemical parameters for the slaughter days far exceeded observations for non-slaughter days. To further establish the relationship between quality of the river water in the rainy season and the dry season, an analysis of variance test established that the calculated value $(F)$ is higher than the critical $F$, thus the hypothesis that the season of the year does not have any effect on quality deterioration of Anwai River was rejected (Table, 4). Diffuse pollution therefore remains a major source of concern as regards river water pollution.

Table 4: Analysis of variance for effect of season on physico-chemical characteristics of Anwai river water

\begin{tabular}{|c|c|c|c|c|c|c|}
\hline ANOVA & & & & & & \\
\hline Source of Variation & SS & $d f$ & $M S$ & $F$ & P-value & F crit \\
\hline Between Groups & 2180.006 & 1 & 2180.006 & 7.084329 & 0.012546 & 4.182964 \\
\hline Within Groups & 8923.945 & 29 & 307.7223 & & & \\
\hline Total & 11103.95 & 30 & & & & \\
\hline
\end{tabular}

Author’s Field work, 2014 


\section{Conclusion and Recommendations}

Water is increasingly being degraded as human populations grow and the utilization of the water bodies are not monitored and controlled. As abattoir activities go unabated and the wastes generated thereof intensify, quality of water and life will be greatly reduced especially as activities within the water body increase. Based on the results obtained for the physicochemical analysis of water samples for this study, the results indicated that allphysico-chemical parameters (downstream sample site) analyzed were above the values obtained at the upstream sample site (control point).

The pollution impact from the study has showed that the downstream which is 5 meters from the slaughter house has been seriously polluted and this occurred mostly in the rainy season. The downstream physicochemical values during rainy season for slaughter days recorded the highest level in allthe parameters investigated. Non-point pollution and non treatment of abattoir effluents have been implicated in the poor quality of the river in the study area. If this practice continues unabated and more so if measure are not taken to develop alternative sources of community water supply, the Anwai community is most likely to face water and health problems.

There dare need to sensitize operators of abattoir on the health and ecological impacts of unregulated effluents from abattoir. Regular monitoring of activities of abattoirs by State Environmental Protection Agency for compliance with hygienic requirements and sanitary regulations governing the operations of abattoir in the country is also recommended.

\section{References:}

Akan, J.C., Abdulrahman, F.I. and Yusuf, E. (2010): Physical and chemical parameters in abattoir waste water sample, Maiduguri Metropolis, Nigeria. The Pacific Journal of Science and Technology. Vol.11, No.1, pp. 640-648 American Public Health Association, America water Works Association, Water Pollution Control Federation. (APHA, 1992): Standard Methods for Examination of Water, $18^{\text {th }}$ Edition, Washington: American Public Health Association.

Chapman, D. (1996). Water Quality Assessments: A Guide to the Use of Biota, Sediments Water in Environment Monitoring $2^{\text {nd }}$ Ed. UNESCO, World Health Organisation, United Nations Environment Programme, London

Gbadegesin, A. S. and Olorunfemi, F. B. (2007), "Assessment of Rural Water Supply Management in Selected Rural Areas Of Oyo State, Nigeria" African Technology Studies (ATPS) Network Working Papers No. 47. Iwara, A.I, Njar, G.N, Deekor, T.N and Ita, A.E (2012): Effect of Adiabo abattoir on the water quality status of Calabar River in Odukpani, Cross 
River State, Nigeria. Continental Journal of Environment Sciences .Vol. 6, No. 2, pp. 36-43

Kosamu, I.B.M, Mawenda,J. and Mapoma H.W.T.(2011): Water quality change due to abattoir effluent: A case on Mchesa stream in Blantyre, Malawi. African Journal of Environmental science and Technology.Vol. 5.No. 8, pp. 589-594.

Sandra, A., Zashow and Gbendra, M. Herman (1996): Health Effects of Drinking Water Contaminants. Established by North Carolina Cooperative Extension

WHO (2010): Water for Health; WHO Guidelines for drinking water quality; World Water Day 2010 